\title{
Wanted: An Effective Land Use Policy and Improved Reclamation
}

Despite the changes in agricultural policy under the Brezhnev-Kosygin regime, Professor Nove would undoubtedly agree that Soviet agriculture continues to labor under the following disadvantages: (1) problems of production, related to the marginal resource base; (2) problems of incentive, which continue to affect farm efficiency and productivity; and (3) problems of administration, which continue to restrict local decision-making and farm autonomy. ${ }^{1}$ For the most part Professor Nove's essay has addressed itself to the last two sets of problems. Because of this, some elaboration of the problems pertaining to the first category seems warranted. Here I want to refer principally to Soviet attempts to deal with the need for an effective land policy and improvements in land reclamation.

The sheer size of the Soviet agricultural base is overwhelming. According to Soviet estimates, the arable area amounts to more than 217 million hectares with an additional 300 million hectares in natural hay and pastures (all categories).$^{2}$ In the past, Soviet geographers have tended to extol the seemingly almost unlimited agricultural potential. Brezhnev, however, in a speech to the Third Congress of Collective Farms meeting in the Kremlin on November 25, 1969 , saw fit to remind the country that the era of optimism was coming to an end. ${ }^{3}$ Pointing out that erroneous conclusions had been drawn from the notion of boundless land resources, the party leader warned the congress that the ratio of arable land per capita had declined to 0.94 hectares and was destined to fall even further. This declining ratio has been brought about by a steady population growth (despite some slowing down in the 1960s), the increasing sprawl of urban areas and industrial enterprises, ${ }^{4}$ and the inundation of good

1. Alec Nove, The Soviet Economy: An Introduction (London, 1961), pp. 182-89.

2. P. M. Zemsky, Razvitie i razmeshchenie zemledeliia po prirodnokhoziaistvennym raionam SSSR (Moscow, 1959), pp. 10-13.

3. Pravda, Nov. 26, 1969.

4. In the absence of any effective control over the use of land, the encroachment of the city and factory on agricultural land has begun to cause considerable concern. The New York Times, June 1, 1966, reported an incident in Kazakhstan where bulldozers under orders of the state construction agency plowed up suburban farmland to make room for apartment buildings. The report referred also to a Soviet source that emphasized the widespread destruction and misuse of valuable farmland. See also, for example, the article by V. Dobrovolsky, director of the Bureau of Land Management, Ministry of Agriculture of the Ukrainian SSR, in Pravda, Mar. 10, 1970. 
arable land as a result of the construction of dams and reservoirs on major rivers. These developments, together with the knowledge that reserves of virgin land suitable for plowing without substantial improvement have been exhausted, require that the regime come to grips with the land question. The Draft Principles of Land Legislation, adopted late in 1968 and designed "to provide a firm basis for regulating and further developing both all-union and republic land legislation by codifying it" is undoubtedly a step in the right direction. ${ }^{6}$ But it should not be the last word. At any rate, legislation with respect to the land, together with improved farm land use, measures to combat drought and erosion, and more effective drainage of wet lands, could bring beneficial results. However, such an extensive program will entail substantial investments, the results of which will not be apparent for several years to come.

Because of the nature of the terrain and climate, much of the arable area is exposed and subject to severe erosion. This is especially true of the steppe, where crop practices in some areas have aggravated the problem. Wind erosion has been particularly damaging in those oblasts between the Lower Don and the Altai Mountains-oblasts that shared in the virgin lands program. High grain delivery quotas have resulted in overplowing and overcultivation with a substantial reduction in fallowing, both absolutely and relatively. In 1963, for example, fallow land constituted only 0.6 percent of the cultivated area in West Siberia and reached only 5.3 percent of the drier grain-producing regions of northern Kazakhstan. By contrast, in the prairie province of Saskatchewan-a region, which, though similar in some respects to the Trans-Ural Steppe, is not climatically analogous-fallowing normally is practiced on a third or more of the land. In the Soviet Union there was some improvement in 1964 after the very poor harvest of the preceding year, with 4.5 percent of the land left in fallow in West Siberia and 11.6 percent in the Virgin Krai. ${ }^{6}$ However, from 5 to 6 million hectares of steppe cropland are said to be subjected to wind erosion annually, with the loss of approximately 1.5 million hectares of crops. ${ }^{7}$ Severe dust storms average twelve per year in the steppe, fifteen in the dry steppe, and eight in the wooded steppe. ${ }^{8}$ The reduction of grain quotas under the new regime, as Professor Nove has noted, should in turn lead to a wider use of fallowing in the steppe, but unfortunately it cannot replace the top soil already lost through deflation.

A number of measures, many of which date to the last century, have been adopted to combat the effects of drought and wind erosion. Chief among these

5. Pravda, Dec. 14, 1969.

6. Ekonomika sel'skogo khoziaistva, 1965, no. 7, p. 87.

7. Akademiia nauk SSSR, Institut geografii, Prirodnye resursy Sovetskogo Soiusa: Ikh ispol'zovanie i vosproizvodstvo (Moscow, 1963), p. 128.

8. V. V. Zvonkov, Vodnaia i vetrovaia eroziia zemli (Moscow, n.d.), p. 87. 
measures in the steppe has been the planting of protective forests or shelter belts. Stalin in 1948 engineered a major fifteen-year shelter belt program, but the record to 1952 was not widely successful, especially in the drier regions. ${ }^{9}$ We have found in the United States generally that where precipitation falls below 15 inches annually shelter belts fail to mature. If they survive at all, their effectiveness relative to the microclimatology and to soil moisture is minimal, for their usefulness depends on depth and height of plantation. Though the belts result in a cutting back of the crop area of from 3 to 6 percent, they could contribute, according to Soviet estimates, to a 20 to 30 percent increase in yields. However, of the 3 million hectares planted to 1956 only about 1 million survived, and despite the impressive target of the fifth FiveYear Plan and a considerably more modest Seven-Year Plan goal, there was little change through the $1960 \mathrm{~s}^{10}$ (The shelter belts that this writer observed in the North Caucasus piedmont in 1968 seemed sturdy enough, but whatever beneficial results they may have had, they obviously could not protect the fields from another calamity-crop flattening hail.)

Although throughout much of the steppe (especially along the Lower Volga, in the southern Urals, and in northern Kazakhstan) the shelter belt program has not significantly improved yields, steppe irrigation programs seem to have had more success, and they offer, perhaps, greater potential. Whereas in 1950 only about 13 percent of Soviet irrigation occurred within steppe regions (mainly in European Russia), by 1965 it entailed about 25 percent, an absolute increase in the fifteen-year period of about 2 million hectares. Much of this gain was registered in the North Caucasus and the Ukraine. Indeed, in the Dnieper basin alone, after a slow start, the growth has been impressive : the irrigated area was increased by almost half a million hectares between 1960 and 1967.11 And such developments as this seem to be only the beginning.

However, the "calamitous situation" in the Volga basin-to quote Brezhnev-remains. ${ }^{12}$ In 1960 there were only 131,000 hectares of irrigated land in the basin. The creation of the Volga "cascade" has not been of great significance in providing water for irrigation, for the obvious reason that the river accounts for 80 percent of the surface inflow to the Caspian Sea. A major diversion of Volga water for irrigation purposes cannot be attemptedthat is, if further substantial reduction in the level of the sea (already steadily falling) is to be prevented-without additional and sizable inputs, including

9. Forestry and Forest Industry in the U.S.S.R. (Washington, D.C.: Department of Agriculture, Forest Service, 1961), pp. 18-21. Also G. R. Eitigen, Les v stepi (Moscow, 1959), pp. 4-6.

10. Prirodnye resursy Sovetskogo Soiuza, p. 132.

11. Pravda, Jan. 19, 1968. Indicated in these data are the irrigated areas of the Northern Crimea, which also receive water from the Kakhovka reservoir.

12. Pravda, Nov. 26, 1969. 
presumably the diversion southward through the Kama of Vychegda and Pechora river water..$^{13}$ But as of 1970 the latter scheme appears to have been shelved, at least for the immediate future. How Brezhnev expects to solve the centuries-old problem of drought along the Volga through irrigation, therefore, is not clear. Moreover, some consideration must be given to the adverse effects that power dams have had on the grazing capacity of flood plains downstream. This is especially true of the Volga-Akhtuba plain, where the cessation of natural periodic inundation has led to a deterioration in the composition of the grass cover, with serious consequences for its traditional animal husbandry. At the same time, the needs of industry for Volga power, not to mention the declining catch of the Volga-Caspian fisheries, are matters for continued concern. In West Siberia and northern Kazakhstan irrigation to date has not played an important role in crop production. ${ }^{14}$ The greatest need is in the Ob-Irtysh basin, particularly in the Kulunda Steppe, but because of climatic conditions it seems likely that pastures will benefit more than field crops.

Khrushchev had anticipated that the Soviet Union could satisfy 30 to 40 percent of its grain requirements from irrigated land-from the steppe as well as from Central Asia and the Transcaucasus ${ }^{15}$-but putting such land into low-value crops cannot be the wisest use of so substantial an investment. Cotton is the principal irrigated crop in Central Asia and Transcaucasia, and under existing levels of irrigation probably should not be replaced. Alternatives in the steppe are not numerous, but there are crops, such as sugar beets and some vegetables, that yield more than grain in value per unit area.

To measure progress in terms of areal expansion is one thing, to do so in terms of efficiency is another. In the Ukraine and Moldavia the ratio of irrigated land to total area with an irrigation network was, in 1960, 79 percent. It was as low as 63 percent in the RSFSR and 75 percent in Kazakhstan, but averaged 80 percent in the Transcaucasian and 87 percent in the Central Asian republics. ${ }^{10}$ The discrepancy, which tends to fluctuate from year to year, has many causes : inadequate preparation of the land to be irrigated, a withdrawal

13. See S. L. Vendrov et al., "The Problem of Transformation and Utilization of the Water Resources of the Volga River and the Caspian Sea," Soviet Geography, 5, no. 7 (September 1964): 23-24; N. I. Shishkin, "On the Divergence of the Vychegda and Pechora Rivers to the Basin of the Volga," Sovict Geography, 3, no. 5 (May 1962): 46-57; George A. Taskin, "The Falling Level of the Caspian Sea in Relation to Soviet Economy," Geographical Revierv, 44, no. 4 (1954): 508-27; and also Philip P. Micklin, "Soviet Plans to Reverse the Flow of Rivers: The Kama-Vychegda-Pechora Project," Canadian Geographer, 13, no. 3 (1969) : 199-215.

14. A. I. Dzens-Litovsky, "K voprosu ob ispol'zovanii vod velikikh sibirskikh rek," Goograficheskii sbornik, 4 (Moscow, 1954): 13; N. A. Mosienko, "Oroshenie v Kulundinskoi Stepi," Zemledelie, 1964, no. 3, p. 48. See also G. A. Petro, "Skhema kompleksnogo ispol'zovaniia reki Irtysh," Problema vodobespecheniia tsentral'nogo Kazakhstana (Moscow, 1960), pp. 320-25.

15. Prirodnye resursy Sovetskogo Soinza, p. 104.

16. Ibid., p. 105. 
of land previously irrigated, faulty irrigation networks, secondary salinization, and simply a lack of water. In many instances the land programmed for irrigation is dry farmed, in which case the irrigation ditches hinder the use of agricultural machinery. The most critical defect in Soviet irrigation-and this is particularly true of the dry regions-is that more than half the water conducted by the canals, most of which are open and unlined, is lost in seepage, spillage, and evaporation, and never reaches the fields. The seepage and spillage, moreover, produce salinization and waterlogging, in either case reducing substantially. (if not destroying) the productivity of the soils. In the cotton-producing regions, it is estimated that approximately 800,000 hectares of land have become to some extent salinized, yielding 5 to 7 centners less than soils free of salts. The irrigable potential for the arid Central Asian republics is always painted in glowing colors, but even assuming that the water is available through the Ob-Irtysh diversion project or the tapping of underground fresh water reserves, ${ }^{17}$ without an increase in efficiency of water use (not to mention an improvement in the training of reclamation workers, a requirement often cited by Soviet writers), much will be lost.

The new regime, as Professor Nove states, has also suggested that a major effort be undertaken to expand drainage and to increase the application of lime to soils-projects that pertain mainly to the nonchernozem zone of European Russia. The area of marsh and poorly drained land is extensive and widespread throughout the forest region. However, improvement has come only slowly. Certainly it is true that between 1955 and 1965 the area drained increased from 8.2 million hectares to 10.6 million (the latter falling short of the goal for the Seven-Year Plan by 1.8 million).$^{18}$ However, in 1965 only 7.1 million were in actual use. Of that, only 3.3 million were actually in crops, and their contribution to the grain-potato-sugar beet supply may have been very modest because of the heaviness of the soils and, in part, the relatively short growing season. Meanwhile, not only do extensive areas of meadows and pastures require improvement, but even wide areas around such heavily populated places as Moscow and Leningrad remain useless. Moreover, the flooding of good land as a result of the construction of dams has also had an

17. G. A. Mavlianov and S. Sh. Mirzaev, "Conditions and Prospects for Irrigational Development in Central Asia and Problems of Utilization of Underground Waters," pp. 7-9, in Abstracts of the Reports, Tashkent Symposium on "The Influence of Irrigation on Secondary Salinization, Chemical Composition and Groundwater Regime," Tashkent, Aug. 6-12, 1962 (in English). Gerasimov, however, notes that available surface waters would seem to be sufficient to irrigate over 37 million acres (cf. 13 million in 1965), but a "whole series of as-yet-unsolved scientific and technical problems" remain to be solved. I. P. Gerasimov, "Basic Problems of the Transformation of Nature in Central Asia," Soviet Geography, 9, no. 6 (June 1968) : 445; see also Robert A. Lewis, "The Irrigation Potential of Soviet Central Asia," Annals of the Association of American Geographers, 52, no. 1 (1962) : 99-114.

18. Prirodnye resursy Sovetskogo Soinza, p. 98. 
adverse effect on agriculture in north central Russia as well as in West Siberia. By 1965 it was anticipated that more than 5 million hectares were to have been inundated, with the total possibly to reach 30 million in the future (of which 1.5 million will represent lost cropland and approximately 10 million haylands and pastures). With farm productivity being what it is, it is highly doubtful that the Soviet Union can afford to surrender such an area to reservoirs.

A final comment on the soils of the nonchernozem zone. They are noted above all for their acidity ( $\mathrm{pH}$ values range from 6.5 to 4 or less). They are also low in organic content, are sandy and stony, and suffer widely, as noted above, from poor drainage. Nonchernozem soils can be made to produce, if allowance is made for the short growing season, and if there are heavy applications of lime, organic matter, and other fertilizers. An estimated 50 to 60 percent of the cropland needs liming, and in some districts the ratio runs as high as 90 percent or more. The lighter soils need building up, but it is common knowledge that organic fertilizers have not been available in sufficient amounts in the past, or if they were available, they were not applied adequately. The same story is true for the use of peat, deposits of which are widespread in the nonchernozem zone. Presumably the shortage in chemical fertilizers is being overcome, but their effectiveness will depend on type, amount, and manner of application. Finally, the nonchernozem zone (in part at least), together with the wooded steppe and the steppe to the south of Moscow, where relief is substantial, are subject also to rather serious water erosion, evidence of which is readily apparent along the trunk line from Moscow to Donetsk.

Essential to an effective land use policy and improved melioration is a comprehensive cadastral survey of the USSR. From that a systematic and qualitative evaluation of land in terms of yield capacity can be developed. Such an evaluation depends upon detailed and uniform soil mapping; however, up to now large-scale soil maps have reportedly been available for only half the agricultural area of the Union. Until this time-consuming task has been completed, therefore, directives exhorting Soviet farm managers, factory directors, timbermen, and the like to adopt a cautious approach to the use of land will make little sense. If priorities based on the long-term requirements of the society as a whole are not established - the problems associated with such analysis being fully recognized-a continual decline in the arable land per capita will undoubtedly only worsen the Soviet agricultural picture and lead to even more general deterioration of the Soviet physical environment. 